\title{
Chapter 22 \\ Technology for Climate Justice: \\ A Reporting Framework for Loss \\ and Damage as Part of Key Global Agreements
}

\author{
Marc van den Homberg and Colin McQuistan
}

\begin{abstract}
Technology plays a critical role in the ability to retain, reduce or transfer climate risk or address impacts. However, vulnerable communities do not fully benefit from existing technology, whereas they are disproportionally impacted by climate change. This chapter assesses how technology can shape limits to adaptation and how to report on this injustice as part of key global agreements. We develop an access, use and innovation of technology framework. As a case on a relevant technology, we test it on transboundary early warning systems in South Asia. We find that only a limited set of the state-of-the-art technologies available globally is accessed and used. Insufficient capacity and funding result in the bare minimum, largely copycat type of technology. As climate change progresses, demands on technology increase, whereas, if no action is taken, the technology remains the same widening the adaptation deficit. A better understanding of the crossover from disaster risk reduction to climate adaptation and the emerging policy domain of loss and damage allows trade-offs in terms of reducing risks through greater investment in technologies for adaptation versus absorbing risks and then financing curative or transformative loss and damage measures. We argue that attention to especially distributive, compensatory and procedural climate justice principles, in terms of distributing technology, building capacity and providing finance, can help to motivate support for widening the technology spectrum available to developing countries. We
\end{abstract}

M. van den Homberg $(\bowtie) \cdot$ C. McQuistan

Practical Action, Rugby, UK

e-mail: marcjchr@gmail.com

C. McQuistan

e-mail: colin.mcquistan@practicalaction.org.uk

(C) The Author(s) 2019

R. Mechler et al. (eds.), Loss and Damage from Climate Change, Climate Risk

Management, Policy and Governance, https://doi.org/10.1007/978-3-319-72026-5_22 
propose as part of comprehensive risk management that, first, an inventory should be developed how of technologies shape soft and hard adaptation limits. Second, technology for climate justice might be included in the adaptation communications to support reporting on the expected and experienced impact of measures on loss and damage, at a sufficiently disaggregated level. Third, soft adaptation limits should be levelled by making technology research, innovation and design equitable between those countries having capacity and those not, recognising the commitment to leave no one behind.

Keywords Loss and damage $\cdot$ Flood early warning systems $\cdot$ Adaptation Climate risk management $\cdot$ Climate justice $\cdot$ Sendai framework for DRR Sustainable development goals $\cdot$ Paris agreement

\title{
22.1 Introduction: Unequal Impact of Climate Change and the Role of Key Global Agreements
}

\begin{abstract}
Although anthropogenic climate change is a global phenomenon, its impacts are neither equally distributed over developing and developed countries nor between the rich and the poor. The poor face greater impacts when exposed to natural hazards than the non-poor (Hallegatte et al. 2016). There is evidence that adaptation capacity is and will be exceeded in various instances, requiring attention to loss and damage (L\&D) (see book chapters by Handmer and Nalau 2018; Heslin et al. 2018; Haque et al. 2018; Landauer and Juhola 2018; and the introduction by Mechler et al. 2018). This inequality places the impacts of climate change (and climate variability) and the burden of climate action disproportionately on the most vulnerable (IPCC 2014). At the same time, those developing countries and poor communities that will be most heavily affected by the impacts of climate change have contributed the least (in terms of greenhouse gas emissions) to the problem (Clark 2011). This latter aspect has been discussed under the concept of Climate Justice in the domain of climate change impacts and mitigation. Climate justice is a term used for framing climate change as an ethical and political issue, rather than one that is purely environmental or physical in nature. This is done by relating the effects of climate change to concepts of justice, particularly environmental justice and social justice (see chapter by WallimannHelmer et al. 2018). This chapter focuses on the unequal dimensions of climate justice and, more particularly, it asks how technology can address climate risks for the most vulnerable in a just way, and where the practical limits are to what technology can achieve.
\end{abstract}




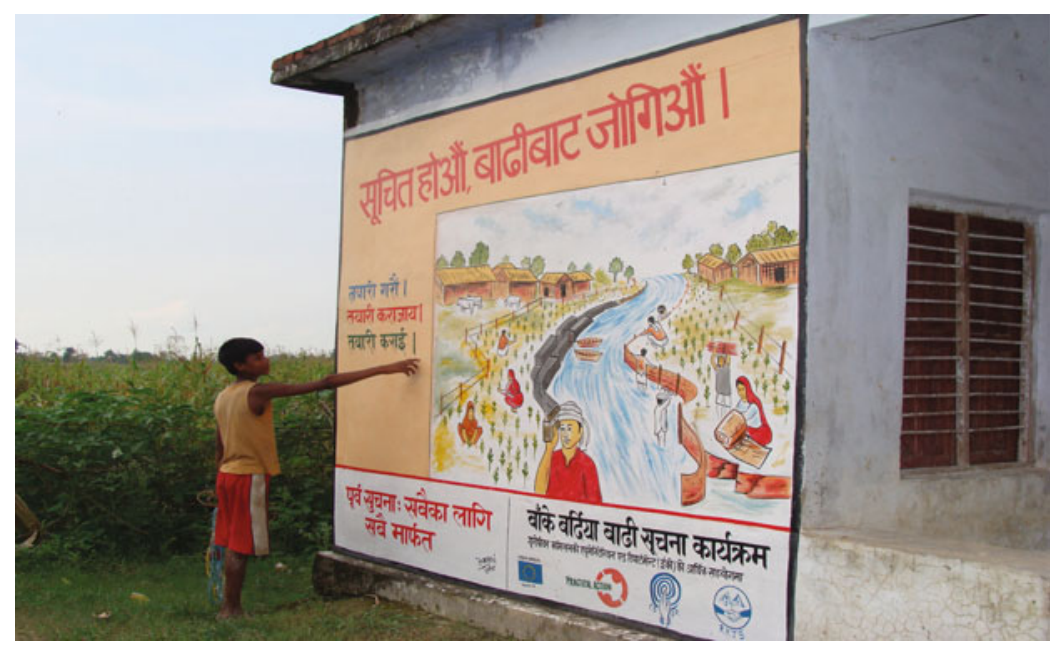

Fig. 22.1 Community information board in the Banke and Bardia district in Nepal explaining appropriate flood mitigation measures and the community-based early warning system

More specifically, we aim to disentangle the relationship between technology and loss and damage, adaptation and disaster risk management from a climate justice perspective through three guiding questions (1) How can the role of technology in reaching climate justice for vulnerable and poor communities be assessed? (2) How is technology shaping adaptation limits, thereby reducing losses and damages? (3) What are the current transparency mechanisms of key global agreements (and related regional, national and local ones) with relevance for climate change and how do these cover losses and damages and unveil technology (in)justice? We use an exploratory and mostly qualitative research design to address these research questions. We combine desk research of scientific literature, an analysis of the reporting that is available on the global agreements (retrospectively) and an analysis of what will be reported in the future (forward-looking), national and local level documents in relation to disaster risk management on floods (the dominant climate-related risks globally) as well as a case study. The case study investigates transboundary flood community-based early warning systems (EWS) that are operational in the Brahmaputra river basin (Bangladesh-India) and in the Karnali river basin (India-Nepal; Fig. 22.1 shows community information on such an EWS in Nepal).

The chapter structure is as follows. Section 22.2 addresses research question (1) and presents five components to characterise the role technology plays in reaching climate justice. Section 22.3 categorises how technology can shape adaptation limits (research question 2). Section 22.4 shows how the plethora of reporting and reviewing mechanisms of the key global agreements and their regional, national and local counterparts cover loss and damage only to a limited extent and do not adequately unveil injustices (research question 3). Section 22.5 brings the results of these three sections together in a coherent framework that can be used to assess technology for 
climate justice in global agreements and applies it to a case study on EWS. The case study demonstrates far from equitable access to early warning and early action information, as well as untapped technology and innovation potential. Section 22.6 shows how the framework can be used to guide action. We identify windows of opportunities to include technology for climate justice more strongly into the crossover from adaptation to $L \& D$ in the climate agreement, but also to make sure there is a linkage to the other key global agreements.

\subsection{Technology for Climate Justice}

Climate justice is an umbrella term bringing together distributive and compensatory (see chapters by Wallimann-Helmer et al. 2018; Schinko et al. 2018), retributive, transitional $^{1}$ (Klinsky and Brankovic 2018) and procedural justice (Tomlinson 2015; Walker 2009) perspectives. Climate justice has spatial and temporal dimensions. As an example, distributive justice is based on an inter-generational or an intragenerational perspective, and compensatory justice on a retrospective one. We indicate how different justice dimensions could influence the means of implementation of the Paris Agreement through backward-, forward- and both backward- and forwardlooking actions in Fig. 22.2. Mitigation and adaptation are often discussed under one and the same heading of climate justice, whereas there are clear distinctions between what climate justice means in terms of duties for these two pillars (see chapter by Wallimann-Helmer et al. 2018). Climate justice aims to address inequalities and is hence key for the L\&D debate. We focus on the role that technology could play in delivering climate justice. Technology and innovation are important enablers for climate actions. In addition, technology can be seen as a way to overcome political sensitivities. For example, a technological innovation process makes use of equitable procedures that engage all stakeholders in a non-discriminatory way, a form of procedural justice (Walker 2009).

Disaster risk reduction (DRR), climate change adaptation (CCA) and L\&D strategies can minimise current and future losses and damages by protecting people, properties and ecosystems against climate-related stressors for flood risk (see box 22.1). Even though these strategies comprise a plethora of different hard and soft risk management measures, technology plays a crucial role. Inadequate or inappropriate technology reduces the range of available options as well as their effectiveness in reducing or avoiding risk from increasing rates or magnitudes of climate change (IPCC 2014). In terms of climate justice, access to technology and its benefits are not fairly shared.

\footnotetext{
${ }^{1} \mathrm{~A}$ way to recognise and at least partially remedy past injustices while also building a sense of cooperation. It helps to overcome tension about the ideal relationship between responsibility for past and future action and avoids the liability debate (Walker 2009; Klinsky and Brankovic 2018).
} 


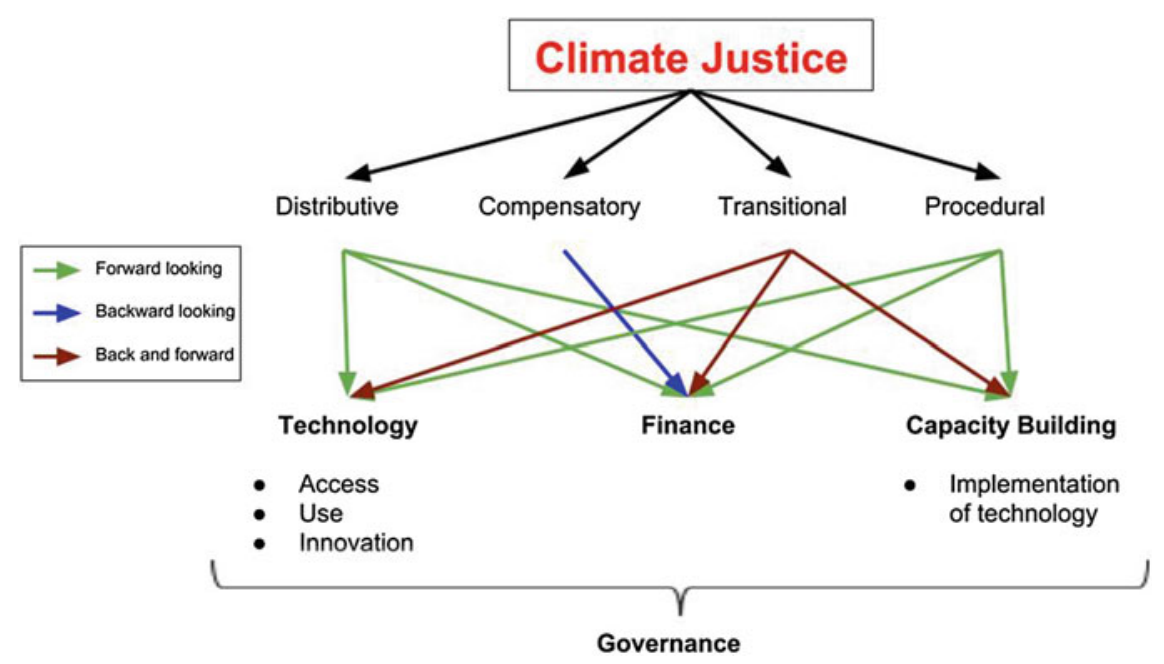

Fig. 22.2 Overview of underlying climate justice principles and means of implementation

\begin{abstract}
Box 22.1 Importance of technology to reduce flood risk
Our examination focuses on flood risk, as hydro-meteorological hazards cause the largest economic, social and humanitarian climate-related losses. Between 1980 and 2013, global direct economic losses due to floods exceeded \$1 trillion (2013 values), and more than 220,000 people lost their lives (Winsemius et al. 2015). In 2016, the high number of flood events, including river flooding and flash floods, was exceptional and accounted for $34 \%$ of overall losses, compared with an average of $21 \%$ over the past 10 years (Munich Re NatCatService 2017). Globally, economic losses due to flood events have increased, due to the expansion of population and property in floodplains (IPCC 2012) resulting from poorly planned socio-economic activities. Climate change increases the frequency and aggravates the severity of many of these hazards (IPCC 2014). In Asia and the Pacific, $32 \%$ of the economic losses from natural disasters in 1970-2013 were due to floods (UNESCAP 2015). Calculations for Bangladesh predict, for example, an average increase of flooded area of $3 \%$ in 2030 and $13 \%$ by 2050 , combined with an increase of inundation depth in most areas that are currently already at risk, exposing $22 \%$ more of the population (World Bank 2010).
\end{abstract}

There are several frameworks developed by international organisations and Nongovernmental organizations (NGOs) to describe the transfer and diffusion of climate technologies. As one example, UNEP developed a framework to identify and analyse these barriers as part of technology needs assessments (as we will discuss in Sect. 22.4) (Boldt et al. 2012). They identified four key groups of barriers (or enabling environments). Klein et al. (2014) used four key considerations for technology as an adaptation constraint that are closely related to the barriers. For example, access is directly linked to the economic and financial conditions. The effectiveness 
Table 22.1 Practical Action's framework for technology justice with five components

\begin{tabular}{l|l}
\hline $\begin{array}{l}\text { Technology justice } \\
\text { component }\end{array}$ & Description \\
\hline Access & Equitable access to services \\
\cline { 2 - 2 } & Equitable access to technology and knowledge \\
\hline Use & $\begin{array}{l}\text { Technology use can have a negative impact on future generations and a } \\
\text { negative impact on certain groups in society, while beneficial to others. } \\
\text { Sustainable, intergenerational use should be promoted and enabled }\end{array}$ \\
\hline $\begin{array}{l}\text { Technological } \\
\text { innovation and } \\
\text { implementation }\end{array}$ & $\begin{array}{l}\text { Considerable untapped potential in implementing and developing } \\
\text { technology to push the limits of what can be managed and absorbed by the } \\
\text { poor and vulnerable. Unfortunately, technological development and } \\
\text { innovation are focused on creating new markets or exploiting existing } \\
\text { markets for those who can afford to pay. Investments therefore focus on } \\
\text { high tech technologies. Ideally, innovation and implementation of } \\
\text { technologies is driven by the most pressing social and environmental } \\
\text { challenges and with the equitable involvement of the poor and vulnerable }\end{array}$ \\
\hline Governance & $\begin{array}{l}\text { Governance should enable access to the technology and knowledge that is } \\
\text { required, promote the use of inclusive technologies and curb those that } \\
\text { adversely affect the environment }\end{array}$ \\
\hline Finance & $\begin{array}{l}\text { Adequate and well targeted finance from different sources funds } \\
\text { technology access, use, innovation and governance prioritised to respond to } \\
\text { the critical loss and damage challenges }\end{array}$ \\
\hline
\end{tabular}

in managing climate risk links to research and technological capacity but also to the social acceptance of a new technology. Both frameworks have a multi-stakeholder perspective and show that it is never about a straightforward transfer of technology. If that is done, like with agricultural machinery (Trace 2016) or advanced flood modelling software, chances are very high the technology is abandoned and not used. As an NGO example, the technology justice framework launched by Practical Action (Practical Action 2016) rethinks the role of technology from the perspective of the poor and vulnerable (Trace 2016) and consists of three components: Access, Use and Innovation. We complement these with Governance and Finance (see Table 22.1), creating five components that are closely linked to the three Paris means of implementation.

\section{Access to Services and Access to Technology and Knowledge is Not Equal}

The poor have almost always more limited access to basic services such as water and energy, but also to disaster-related services such as early warning and climate information (Raworth 2012). In addition, developing countries and, within those countries, the poor more than the rich have limited access to technology and knowledge (Traces 2016). In the case of an EWS, further discussed below, even if vulnerable communities receive early warning information, they often lack access to the knowledge required for early action (Cumiskey et al. 2014). Christiansen et al. (2011) extracted about 165 unmet technological needs related to adaptation (and mitigation) from technology needs assessments carried out in developing countries. Examples 
include applications to agriculture in Cambodia and Bangladesh and coastal zones in Thailand. In many of these cases patents and other forms of intellectual property protection constrain technology transfer, especially from developed to developing countries (Klein et al. 2014). Between 2008 and 2010, 262 patents were published making specific claims to abiotic stress tolerance (such as drought, heat, flood, cold and salt tolerance) in plants. Just six corporations, including DuPont, BASF and Monsanto, control $77 \%$ of these patents in relation to climate-ready crops (ETC Group 2010). National Meteorological and Hydrological Services (NMHS) in developing countries do not have access to the same level of knowledge and technology as developed countries. For example, digital elevation model data at sufficiently high resolution, required for more accurate flood risk modelling, is usually not affordable (Simpson et al. 2015).

\section{Use of Technology is Unjust}

Technologies are often used in unsustainable ways, depleting resources and stacking up problems for future generations (Practical Action 2016). For example, industrialised agriculture leads to biodiversity loss, thereby limiting the options available to farmers to respond to climate-induced shocks and stresses. In some circumstances, the use of technologies to reduce short-term risk and vulnerability can contribute to increased vulnerability to extreme events for future generations (Etkin 1999; Moser 2010). This was seen in the impacts of Hurricane Katrina, where a flood defence system enabling construction in a floodplain decades before failed, with catastrophic consequences for the population of New Orleans in 2005 (Freudenburg et al. 2008; Link 2010). Flood protection levees are known to eliminate overbank flooding, causing diminished sediment accumulation and eventual wetland loss, whereas wetlands are beneficial as a natural buffer for hurricanes (Turner et al. 2006).

\section{Technological Innovation and Implementation for the Most Vulnerable}

Technological innovation and implementation is rarely driven by the most pressing social and environmental challenges. Technology justice argues for the involvement of the poorest and most vulnerable so that technologies deliver impacts on our biggest human challenges and are not driven by a profit motive alone (Practical Action 2016). It requires looking into how technologies can empower vulnerable communities and which corresponding capacities they need to best utilise and further innovate these technologies. This requires a critical examination of not only how technology reduces vulnerability but also how the use of some technologies can increase vulnerability to disasters, for example by degrading the local environment or by creating a false sense of security.

\section{Governance Mechanisms to Enable Access}

Appropriate governance enables access to the technology and knowledge that is required, promotes the use of inclusive technologies and curbs those that adversely affect the environment (Practical Action 2016). Governance mechanisms should ensure that there is a coherence between the global and national/local policies and that technologies required for implementing climate risk management (CRM) are considered in national and local public investments. Governance mechanisms are 
directly related to the ownership and institutional arrangements around the use of technology (or orgware, as we will introduce in the next section).

\section{Financial Support is Essential}

The tragedy is that the poor and vulnerable are usually more exposed to natural hazards, but not in a position to invest in technology that could potentially reduce their exposure (Hallegatte et al. 2016). Similarly, at a national level, the least developed countries will in many cases have to apply their limited funds to deal with the losses and damages incurred, rather than to invest in adaptation. International climate change financing mechanisms are increasingly charged with addressing this funding gap, but currently at low levels. In addition, economic valuations such as cost-benefit analysis that are used to justify expenditures inter- and intra-nationally are not well designed to consider the poor and vulnerable in an equitable way, as, in absolute terms, the asset loss will be higher in the richer and more wealthy areas than in poorer areas (Hallegatte et al. 2016).

This shows that developing countries have severely lower institutional and technological capacities to pursue climate-resilient development pathways (IPCC 2014) as compared to developed countries. Technology for climate justice requires rethinking access, use, innovation, finance and governance from the perspective of the poor and vulnerable and making sure there is justiceand equity in these components. The transfer and diffusion of technologies for risk management can be assessed against the technology justice components at the global, regional, national and local level, to which we turn after describing the spectrum of technologies for dealing with climate-related risks.

\subsection{Technologies for Public and Private Actions to Address Loss and Damage}

Technology involves hardware, software and orgware (Christiansen et al. 2011; Boldt et al. 2012). Hardware refers to the tangible aspects such as capital goods and equipment and includes flood resistant crops and new irrigation systems. Software refers to the capacity and processes involved in the production and use of the hardware and ranges from know-how (e.g. manuals and skills, awareness-raising, education and training) and experience to practices (e.g. agricultural management, cooking and behavioural practices). Adaptation methods and practices that may not normally be regarded as technologies, such as insurance schemes or crop rotation patterns, may also be characterised as software (UNFCCC 2006). Orgware is equally important from an implementation point of view and relates to the ownership and institutional arrangements of the community or organisation where the technology will be used. It includes those organisations involved in the adoption and diffusion process of a new technology. 
Adaptation measures either withstand, transfer or reduce risks, with risk reduction preferred over withstanding or transferring risk. Apart from managing the downside risk, there is also in some cases potential for up-side risk, where a positive impact results. For example, changing to flood-resistant crops might not only lower the down-side risk of losing a harvest during a flood, but might also increase the up-side risk by a higher yield. Maladaptation results if adaptation measures create additional risks instead of reducing them. O'Brien et al. (2012) give an example where irrigation might be beneficial in the short-term, reducing a farmer's vulnerability, but in the long-term increases vulnerability when the non-renewable source used for the irrigation is depleted. "Hard" engineering solutions can be expensive and may not cover costs and risks equally for all stakeholders across time. As an example, the Nanbéto dam in Togo reduced total days with flood conditions for downstream communities, but also increased their flood vulnerability every time an overspill and subsequent poorly managed and communicated release of water took place (Climate Centre 2017). In the United States, past building in floodplain areas downstream from dams that have exceeded their design life has become a major concern (O'Brien et al. 2012). In this case, losses and damages are being exacerbated for the more vulnerable communities. "Softer" solutions such as ecosystem restoration or stress tolerant crop varieties may provide a range of benefits now and in the future (IPCC 2014; van der Geest and Warner 2015) and can be very cost-effective sustainable solutions.

In the case of L\&D risks that are "beyond adaptation" (see Box. 22.2 and introduction by Mechler et al. 2018), risks can only be absorbed, and we distinguish hard and soft adaptation limits. A soft adaptation limit means that adaptation options are currently not available to those affected, but might become available with cultural, social and economic change or technology and innovation (Dow et al. 2013). In other words, the limit is mutable. As an example, Alaskan native villages threatened by coastal erosion and inundation have, from their perspective, no available options to maintain their way of life (which is for them an intolerable risk), since protecting their infrastructure is economically not feasible (Klein et al. 2014). Hard adaptation limits occur if no adaptive actions are available now or in the future to avoid intolerable risks (Verheyen 2012; Klein et al. 2014). For example, protection against sea-level rise is in some cases considered impossible, no matter what welfare growth, institutional changes or technological innovations emerge (Dow et al. 2013). But, even hard adaptation limits can be dynamic over time. The inability to breed rice varieties that pollinate above $32-35{ }^{\circ} \mathrm{C}$ is currently considered as a hard limit (Klein et al. 2014). However, heavy investments in research might someday result in shifting pollination temperature limits upward (Dow et al. 2013). 


\section{Box 22.2 Risk management and limits approach to L\&D}

The risk management perspective classifies risks as either acceptable (no additional action required), tolerable (action required considering costs and other constraints) or intolerable (action required irrespective of constraints). It makes clear that, once standard adaptation in the form of DRR, CCA or development is no longer feasible in the intolerable space, transformative or curative action is required (Mechler and Schinko 2016). The limits to adaptation perspective focuses on soft and hard limits to adaptation (Klein et al. 2014; Dow et al. 2013). A cross-cutting distinction is between whether the option represents incremental, fundamental or transformative adjustment (Schinko and Mechler 2017). Kates et al. (2012) distinguish between incremental and transformational adaptation. The former aims to improve efficiency within existing technological, governance and value systems, whereas transformative adjustments may involve changes in some of the fundamental attributes of those systems. Kates et al. (2012) consider three groups of transformative actions, i.e. those adopted at a much larger scale or intensity, those that are truly new to a particular region or resource system, and those that transform places and shift locations. Schinko and Mechler (2017) use the connotation "transformative" to denote a profound change in risk management going beyond traditional adaptation measures, whereas Kates et al. (2012), with "transformational adaptation", refer to an innovative approach of adaptation and include shifting locations, which is strictly speaking no longer adaptation.

Considerable groups of vulnerable people who live in highly exposed and riskprone places and who lack the capacity to adapt have already reached either soft or hard adaptation limits (van der Geest and Warner 2015). Apart from accepting the limit and corresponding escalating losses, one can undertake curative or transformative measures, as we explain also in Box 22.2 on risk management. In the example of Alaskan villages, a transformative measure would be to relocate residents and economic activity away from high risk and increasingly unproductive areas-even though this is deemed politically impossible, given the estimated costs of up to US\$1 million per person (Huntington et al. 2012; Klein et al. 2014). If no transformative action is taken, only curative measures remain as a last resort. This involves redress and rehabilitation mechanisms, when climate change can be established as the key driver, for example, displacement and involuntary migration.

Clusters of technologies can be distinguished that are beneficial for multiple actions. Disaster risk management, such as EWS, and structural/physical technologies, such as ecosystem management, serve only adaptation purposes. Geographical information management and applications are instrumental both in the adaptation and "beyond adaptation" phase, for example for spatial or land-use planning. Technologies for poverty alleviation and livelihood security are clearly distinct. As an example, for livelihood security in the adaptation phase, one can diversify livelihoods by changing agricultural practices to ones that can cope with climate change, whereas for "beyond adaptation" one must find alternative livelihoods and shift from agriculture to, for example services. In this case, there is no longer a strong relationship between the livelihood and natural hazards. 
Table 22.2 gives an overview of actions that public or private actors can take to reduce, retain, transfer or absorb climate risk (Subsidiary Body for Implementation 2012) by giving examples that are drawn from the case study on EWS. For each action, we explain the objective in terms of addressing loss and damage. We also indicate for both the private and public action if the technology required is basic, intermediate or advanced. The first column of Table 22.2 situates the action within the spectrum of policy options. Boyd et al. (2017) and the chapter by James et al. (2018) explain how different actor perspectives on L\&D result in different ideas about what policy options are available for addressing $L \& D$, both ex ante to address the risk of losses and damages and ex post to address impacts that have materialised. They distinguish the adaptation and mitigation, the risk management, the limits to adaptation and the existential perspective; we focus on the risk management and the limits to adaptation perspectives to construct the overview.

\subsection{Reporting Frameworks for Global, Regional, National and Local Policies}

We now turn to analysing key global agreements with their corresponding regional, national and local counterparts regarding their transparency mechanisms in relation to losses and damages and technology as a means of implementation. As tracking of the post-2015 agreements has started only to a limited extent, we include reporting under the pre-2015 agreements in our analysis.

\section{Global Agreements and Risk Management}

Figure 22.3 shows how the risk of losses and damages is associated with climate change and climate variability. These risks can be reduced, retained, transferred or addressed through climate action. There are three major global agreements which guide climate actions and priorities in addressing climate risks to different extents: the Paris Agreement on Climate Action (UNFCCC 2015), the Sendai Framework for Disaster Risk Reduction (UNISDR 2015) and the Sustainable Development Goals (SDG) (UN 2015), all agreed in 2015. The Paris Agreement distinguishes three pillars of climate action: mitigation, adaptation and L\&D. Mitigation will reduce losses and damages by slowing down climate change. Adaptation will reduce risks, but without changing the level of climate change, and result in avoided losses and damage. The L\&D pillar addresses losses and damages as they occur, losses and damages that mitigation failed to reduce and that were beyond the scope of adaptation (van der Geest and Warner 2015; see introduction by Mechler et al. 2018). Climate risk management (CRM) is an integration of traditional approaches of climate change adaptation (CCA) and disaster risk reduction (DRR) as well as transformational actions, and aims to provide stakeholders with relevant decision-support information and tools to face climate risks (IISD 2011; see also chapters by Handmer and Nalau 2018; Heslin et al. 2018; Heslin 2018; Haque et al. 2018; Landauer and Juhola 2018). Comprehensive risk management is used as a broader term that includes all actions aimed at reducing risk regardless of cause. 
Table 22.2 Overview of public and private flood risk actions and their intended effect on losses and damages

\begin{tabular}{|c|c|c|c|c|}
\hline Adjustment & Spectrum and Timing & $\begin{array}{l}\text { Private action; } \\
\text { Tech level: Examples }\end{array}$ & $\begin{array}{l}\text { Public action; } \\
\text { Tech level: Examples }\end{array}$ & Objective \\
\hline \multirow[t]{3}{*}{ Incremental } & $\begin{array}{l}\text { DRR-preparedness. Short-term, } \\
\text { ex ante }\end{array}$ & $\begin{array}{l}\text { Basic: Fishermen } \\
\text { putting fish net around } \\
\text { fishing pond after } \\
\text { receiving early } \\
\text { warning }\end{array}$ & $\begin{array}{l}\text { Basic: NGO locating } \\
\text { relief items closer to } \\
\text { the predicted to-be- } \\
\text { affected area. Increase } \\
\text { response capacity of } \\
\text { communities }\end{array}$ & $\begin{array}{l}\text { Risk reduction; } \\
\text { Limited increase of } \\
\text { avoidable losses and } \\
\text { damages }\end{array}$ \\
\hline & $\begin{array}{l}\text { DRR-risk reduction; CCA. } \\
\text { Medium-term; for next year's } \\
\text { floods; ex ante }\end{array}$ & $\begin{array}{l}\text { Basic: A household } \\
\text { raises its plinths/floors } \\
\text { and diversifies crops }\end{array}$ & $\begin{array}{l}\text { Intermediate to } \\
\text { Advanced: An NMHS } \\
\text { improves its } \\
\text { hydro-meteorological } \\
\text { modelling so that } \\
\text { forecasts with better } \\
\text { lead times and spatial } \\
\text { resolution become } \\
\text { available. } \\
\text { Government-led } \\
\text { irrigation system, } \\
\text { building of dykes }\end{array}$ & $\begin{array}{l}\text { Risk reduction; } \\
\text { Moderate increase of } \\
\text { avoidable losses and } \\
\text { damages }\end{array}$ \\
\hline & $\begin{array}{l}\text { Humanitarian aid. Directly after } \\
\text { floods; ex post }\end{array}$ & $\begin{array}{l}\text { Basic/none: Support } \\
\text { from within the } \\
\text { community }\end{array}$ & $\begin{array}{l}\text { Intermediate: } \\
\text { Post-disaster public } \\
\text { and donor assistance, } \\
\text { such as relief items or } \\
\text { cash transfers to } \\
\text { households and } \\
\text { money to governments } \\
\text { for reconstruction of, } \\
\text { e.g., roads and } \\
\text { embankments }\end{array}$ & $\begin{array}{l}\text { Risk retention; } \\
\text { Compensation for } \\
\text { unavoided losses and } \\
\text { damages } \\
\text { non-attributable to } \\
\text { climate change }\end{array}$ \\
\hline \multirow[t]{2}{*}{ Fundamental } & $\begin{array}{l}\text { DRR and CCA (larger scale or } \\
\text { intensity). Long-term; over } \\
\text { several years; ex ante }\end{array}$ & $\begin{array}{l}\text { Intermediate: Access } \\
\text { interactive voice } \\
\text { response service to get } \\
\text { meteorological and } \\
\text { agricultural advice }\end{array}$ & $\begin{array}{l}\text { Intermediate: } \\
\text { Improving access to } \\
\text { information through } \\
\text { digital inclusion, e.g. } \\
\text { providing early } \\
\text { warning services in } \\
\text { first language of } \\
\text { beneficiaries, voice } \\
\text { SMS early warning } \\
\text { service, nationwide } \\
\text { coverage of mobile } \\
\text { networks, lower } \\
\text { taxation on mobile } \\
\text { users }\end{array}$ & $\begin{array}{l}\text { Risk reduction; } \\
\text { considerable increase } \\
\text { of avoidable losses } \\
\text { and damages }\end{array}$ \\
\hline & $\begin{array}{l}\text { DRR and CCA (new to a } \\
\text { particular region or resource } \\
\text { system). Medium to long-term; } \\
\text { ex ante }\end{array}$ & $\begin{array}{l}\text { Advanced: } \\
\text { Crowdsourcing data } \\
\text { on water levels from } \\
\text { citizens }\end{array}$ & $\begin{array}{l}\text { Advanced: } \\
\text { Dam operator changes } \\
\text { its way of releasing } \\
\text { water by using } \\
\text { advanced forecasting } \\
\text { models. Forecast } \\
\text { based financing. A } \\
\text { rice research institute } \\
\text { develops } \\
\text { flood-tolerant rice }\end{array}$ & $\begin{array}{l}\text { Risk reduction; } \\
\text { Soft adaptation limit is } \\
\text { stretched; what was } \\
\text { considered } \\
\text { unavoidable before } \\
\text { becomes avoidable }\end{array}$ \\
\hline
\end{tabular}


Table 22.2 (continued)

\begin{tabular}{|c|c|c|c|c|}
\hline Adjustment & Spectrum and Timing & $\begin{array}{l}\text { Private action; } \\
\text { Tech level: Examples }\end{array}$ & $\begin{array}{l}\text { Public action; } \\
\text { Tech level: Examples }\end{array}$ & Objective \\
\hline & & $\begin{array}{l}\text { Intermediate: } \\
\text { purchase } \\
\text { micro-insurance }\end{array}$ & $\begin{array}{l}\text { Intermediate: } \\
\text { Micro-insurance, can } \\
\text { be supported by } \\
\text { mobile technology } \\
\text { and/or public-private } \\
\text { partnerships to ensure } \\
\text { commercial viability }\end{array}$ & $\begin{array}{l}\text { Risk transfer; } \\
\text { Adaptation limit not } \\
\text { changed. Insurance } \\
\text { for unavoidable or } \\
\text { unavoided losses and } \\
\text { damages }\end{array}$ \\
\hline & $\begin{array}{l}\text { DRR and CCA (transform } \\
\text { places). Long term; ex ante }\end{array}$ & $\begin{array}{l}\text { Intermediate: } \text { Citizens } \\
\text { contribute to } \\
\text { constructing bio-dykes } \\
\text { or ecological corridors }\end{array}$ & $\begin{array}{l}\text { Intermediate: } \\
\text { build several smaller } \\
\text { dams instead of large } \\
\text { dam. Green } \\
\text { infrastructure such as } \\
\text { bio-dykes; ecological } \\
\text { corridors. Use of } \\
\text { floodplains instead of } \\
\text { building dykes }\end{array}$ & $\begin{array}{l}\text { Risk reduction; } \\
\text { Soft adaptation limit is } \\
\text { stretched; what was } \\
\text { considered } \\
\text { unavoidable before } \\
\text { becomes avoidable }\end{array}$ \\
\hline & $\begin{array}{l}\text { L\&D curative: redress and } \\
\text { rehabilitation. Short term; ex } \\
\text { post }\end{array}$ & $\begin{array}{l}\text { None: Involuntary } \\
\text { migration or staying } \\
\text { put }\end{array}$ & $\begin{array}{l}\text { Intermediate: } \\
\text { Financial } \\
\text { compensation for loss } \\
\text { and damage that can } \\
\text { be attributed to } \\
\text { climate change. } \\
\text { Active remembrance } \\
\text { (e.g. through museum } \\
\text { exhibitions, school } \\
\text { curricula). } \\
\text { Counselling }\end{array}$ & $\begin{array}{l}\text { Risk absorption; } \\
\text { Adaptation limit does } \\
\text { not change. } \\
\text { Compensation for } \\
\text { unavoidable losses } \\
\text { and damages }\end{array}$ \\
\hline \multirow[t]{2}{*}{ Transformative } & $\begin{array}{l}\text { L\&D transformative measures } \\
\text { (shift places). Long term; ex } \\
\text { ante, ex post }\end{array}$ & $\begin{array}{l}\text { None: Voluntary } \\
\text { permanent migration }\end{array}$ & $\begin{array}{l}\text { None: Voluntary } \\
\text { migration of a } \\
\text { complete village }\end{array}$ & $\begin{array}{l}\text { Risk absorption; } \\
\text { Adaptation limit not } \\
\text { changed. Unavoidable } \\
\text { losses and damages } \\
\text { are avoided by moving } \\
\text { away }\end{array}$ \\
\hline & $\begin{array}{l}\text { L\&D transformative measures } \\
\text { (livelihoods). Long term; ex } \\
\text { ante, ex post. }\end{array}$ & $\begin{array}{l}\text { Intermediate (not } \\
\text { hazard related): } \\
\text { Seeking training and } \\
\text { schooling for } \\
\text { alternative livelihoods }\end{array}$ & $\begin{array}{l}\text { Intermediate, not } \\
\text { hazard related } \\
\text { technology: } \\
\text { Alternative } \\
\text { livelihoods. Providing } \\
\text { training and schooling } \\
\text { (e.g. agriculture to } \\
\text { services industry) and } \\
\text { access to new } \\
\text { technologies such as } \\
\text { e-learning }\end{array}$ & $\begin{array}{l}\text { Risk absorption: } \\
\text { Adaptation limit does } \\
\text { not change. } \\
\text { Unavoidable losses } \\
\text { and damages are } \\
\text { avoided by moving } \\
\text { away }\end{array}$ \\
\hline
\end{tabular}

Examples are taken from the EWS case study discussed in this chapter, except for the one on dams building on ongoing forecastbased financing projects in Africa. Source Climate Centre (2017), Coughlan et al. (2016) 


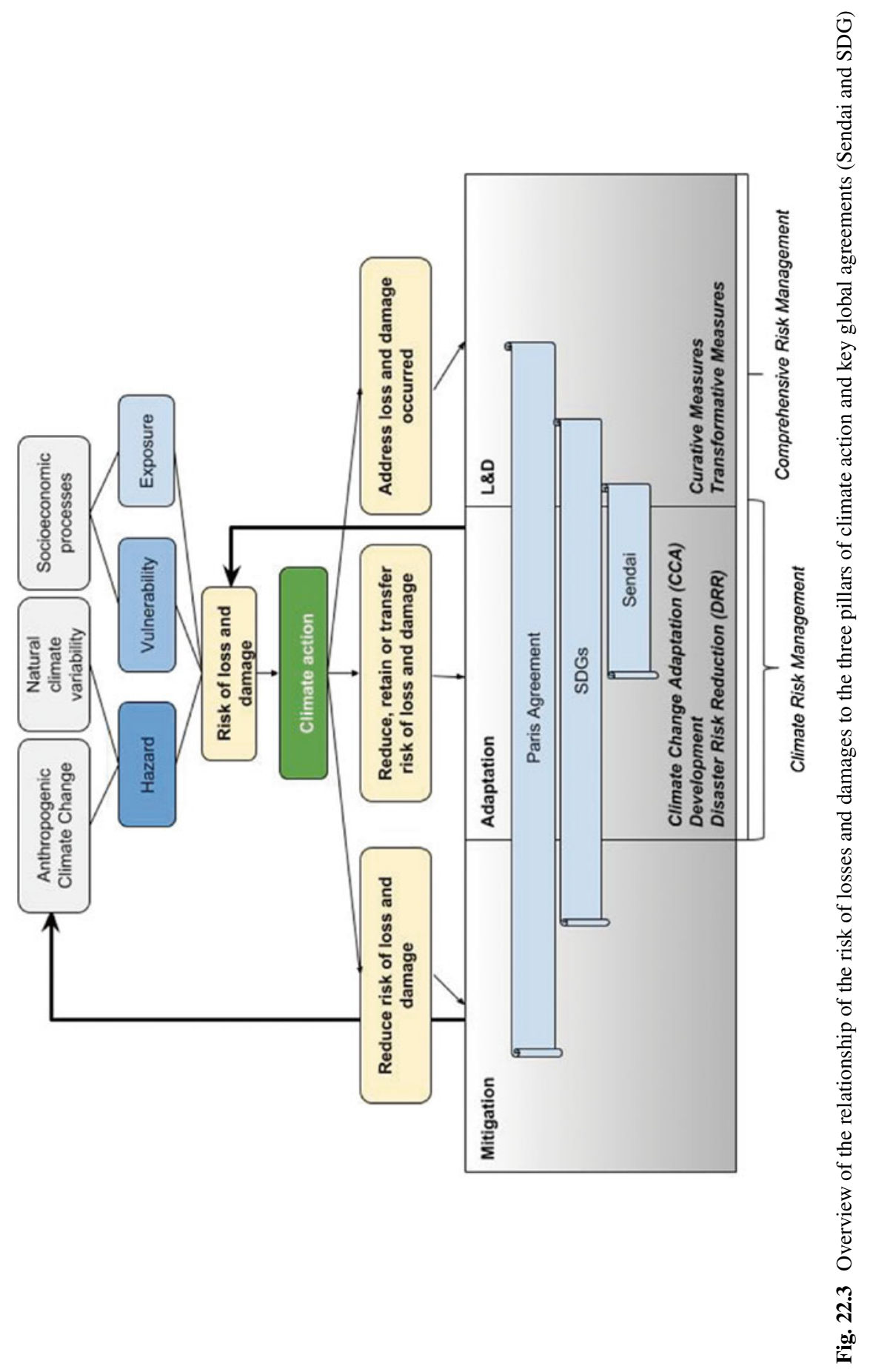


The Warsaw International Mechanism for Loss and Damage associated with Climate Change Impacts (WIM) is the United Nations Framework Convention on Climate Change (UNFCCC) body that has been tasked to develop this pillar (UNFCCC 2013). Sendai, as a framework tailored towards DRR, is part of adaptation. Sendai has indicators on losses and damages and includes paragraphs on relocation of human settlements, ${ }^{2}$ but Sendai does not go into attribution of losses and damages data to climate change and leaves the implications of relocation to the climate regime. The SDG compact encompasses development in many dimensions and has synergies with all three pillars.

Notions of climate justice are relevant for all three global agreements; however, there is now a crucial global opportunity to make climate justice a more coherent part of these three agreements and to ensure that climate actions that follow from these agreements are governed accordingly. Inequities play out more in those countries where existing measures are insufficient to cope with the global warming that will continue even if the ambitious target of the Paris Agreement in terms of limiting warming is met. Therefore, we focus on adaptation, as it can reduce losses and damages for the poorest and most vulnerable in developing countries on a shorter time scale than is possible for mitigation alone. In these countries, investments into transformative adjustments for adaptation and L\&D as a step change to an alternative socio-economic reality may be necessary.

\section{Global Agreements and Transparency: Indicators and Reporting}

As the different agreements evolve, methodologies and terminologies used for providing transparency do so as well. The UNFCCC uses the stringent measurement, reporting and verification (MRV) mechanism (UNFCCC 2014), which is legally binding contrary to the actual mitigation targets in the nationally determined contributions (NDC) that are not dictated by the agreement (Bridgeman 2017). The UN has review or progress reports for the SDGs, and the UNISDR speaks of monitoring and reporting for Sendai, both of which are non legally binding (UNISDR 2015; UN 2015).

The transparency mechanism for the current climate agreements for non-annex I countries starts with the climate pledge, that is (intended) NDCs, where $85 \%$ also have an adaptation component (Pauw et al. 2016). Least developed countries such as Bangladesh and Nepal express their adaptation plans through the short-term national adaptation programme of action (NAPA). Countries are also developing mediumand long-term national adaptation plans. Reporting formats on implementing the convention are currently still different for the non-annex I countries due to "common but differentiated responsibilities and respective capacities" (CBDR-RC). The reporting mechanism consists of National Communications (NC) and biennial update reports (BURs), with sections on both mitigation and adaptation. As one example, the section on adaptation in the NCs for Bangladesh, India and Nepal is much less quantitative than for mitigation (see Box 22.3). These reports present no data on the

\footnotetext{
${ }^{2}$ Paragraph $27(\mathrm{k})$ of the adopted Sendai resolution reads "Formulate public policies, where applicable, aimed at addressing the issues of prevention or relocation, where possible, of human settlements in disaster risk zones, subject to national law and legal systems."
} 
consequence of adaptation measures on impacts and risks. As another example, the second NC for Bangladesh identifies as a gap that there is hardly any research related to Loss and Damage. Scattered throughout the reports is some losses and damages data, but often at a highly aggregate level or very specific.

\section{Box 22.3 Case study findings on reporting frameworks}

We assessed national- and local-level policies in relation to the three global agreements for Bangladesh, India and Nepal. In general, ministries responsible for the environment and forestry develop the national-level climate change policy and investment plans, including the adaptation part. Both Nepal and Pakistan developed local adaptation plans of action (LAPAs) in response to perceived shortcomings of the UNFCCC's NAPAs (Klinsky et al. 2014). Despite successfully integrating vulnerability assessments and prioritising adaptation projects accordingly, the national plan is still seen as an overly broad, top-down estimation that has not adequately captured local needs. Since the impacts of climate change dramatically changed from one village to the next, a topdown process such as a NAPA is considered ill-equipped to cater for meeting local needs (Chaudhury et al. 2014). In Nepal, the LAPA process started mid-2010 and covered, by 2016, 90 village development committees and seven municipalities-the lowest administrative units in the country (Government of Nepal 2016). Nepal's LAPA has succeeded in mobilising local institutions and community groups in adaptation planning and recognising their role in adaptation. However, the LAPA approach and implementation have been constrained by socio-structural and governance barriers that have prevented the integration of local adaptation needs into local plans and thus failed to increase the adaptive capacity of vulnerable households (Regmi et al. 2016). For DRR, each state and district develops its own state and district disaster management plan by adapting the national plan to its local context. The Global Network of Civil Society Organisations for Disaster Reduction has the Frontline programme in which it collects community perceptions of disasters and risk to measure threats, local capacities and underlying development factors, bringing local knowledge to national, regional and global actors. It was one of the few agencies separate from the UN and the agencies that were being assessed that also produced a review of HFA. Frontline continues its programme for the post-2015 agreements, whereby it tries to capture data from local experience and reality on all three key global agreements instead of only on Sendai, by using grounded resilience indicators. Frontline has established baselines during 2015-2016 as a basis for ongoing monitoring during the currency of these frameworks. The Nepalese government, supported by The United Nations Development Programme (UNDP) and in dialogue with development partners, implemented the MDG goals in national-level policies and measures. In some cases, local-level implementation plans, and reporting was completed. Similarly, also for the SDGs, Nepal states in its SDG 2016-2030 National (Preliminary) Report its ambition to combine the localisation of SDGs with political setups at local levels that are willing and capable of handling the development agenda (National Planning Commission 2015).

Article 13 of the Paris Agreement describes the principles for a transparency framework. The new framework will build on the existing mechanisms, but will also introduce the adaptation communication, containing adaptation priorities, implemen- 
tation and support needs, plans and actions. Standardised indicators for adaptation may be useful to make comparisons across countries possible, but are considered more complex than mitigation indicators, as the impact of climate change varies greatly from one country to another. It is important to make adaptation goals more specific and to build on monitoring approaches from different sectors (Transparency Partnership 2017). The transparency framework also aims at aggregating reporting on support offered and received, and gradually converging the review arrangements for developed and developing countries (ECBI 2017). The facilitative dialogue in 2018 supports the development of the transparency framework and also makes clear how it links to the global stocktake, the collective stocktaking of progress towards achieving the paris agreement, which will start for the first time in 2023 and will consider NDCs submitted in 2020 for the period 2026-2030.

Transparency regarding the WIM mechanism in its first phase from 2013 to 2017 can be said to consist of annual work plans, which report mostly on the first two functions of the WIM, i.e. enhancing knowledge and understanding of comprehensive risk management approaches and strengthening dialogue, coordination, coherence and synergies among relevant stakeholders. It is expected that the WIM in its second phase (2017-2022) will be able to work more on its third function, i.e. enhancing action and support. In that case, the transparency mechanism will very likely become more indicator-based.

The Hyogo Framework for Action (2005-2015) (HFA) was monitored through regional, national and, for a limited number of countries, local progress reports, usually at a 3-year interval. In 2015, the UN General Assembly endorsed its successor: the Sendai Framework for DRR 2015-2030, aims to improve on some of the issues encountered under Hyogo, such as the focus in the indicators on input rather than output or outcome, and the lack of clear links to millennium development goals (MDGs) and UNFCCC (Maskrey 2016). Four of sendai's seven global targets are outcome-focused instead of input- or output-focused and have clear links to the SDGs and the climate agreements. Mysiak et al. (2015) state that the wording used in the pre-conference version of the Sendai Framework seems to have been aimed at fortifying the claims advanced under the WIM, claims in terms of accepting liability for the residual risks. Sendai focuses not only on reducing existing risks, but also on preventing new risks and strengthening resilience. Outcome targets are objective and measurable, allowing international benchmarking of progress relative to a quantitative baseline of 2005-2015. A data readiness review for 87 countries has been done (UNISDR 2017). The first progress reports are expected in 2018. Every 2 years, UNISDR publishes the Global Assessment Report for DRR (GAR) as a supportive tool for HFA and Sendai, which monitors risk patterns and trends and progress in DRR while providing strategic policy guidance to countries and the international community.

MDGs (2000-2015) worked with country progress reports usually every 3 years, covering mostly MDG 1 through 7 . MDG 8 was captured through annual MDG Gap Task Force reports. After the UN defined its SDGs, both government spending and donor funding will be tailored-although to a varying degree depending on the specific country and context-to the current scores on these indicators as well as 
the targets that are to be reached in 2030 (Martin and Walker 2017). In 2016 some countries had already submitted a voluntary national review. Table 22.3 shows the losses and damages indicators for SDGs (the MDGs only had indicators in terms of reducing loss of environmental resources and biodiversity).

\section{Transparency: National and Local}

Governments are expected to take ownership of the key global agreements in terms of integration with national planning processes. For example, the National Disaster Management Plan of India states that the country has incorporated substantively the approach enunciated in Sendai. Focal points in each country are responsible for the collection of high-quality, accessible and timely data on the indicators. But also collecting and analysing data at scales greater than national boundaries is required, as disasters do not stop at national borders. Key global agreements and several regional, national and local policies are interrelated, and has each its specific means of implementation. Therefore, regional follow-ups and reviews are held regularly based on the national-level analyses and contribute to follow-up and review at the global level.

\section{Means of Implementation: Technology}

CBDR-RC is a principle within the UNFCCC that acknowledges the different capabilities and differing responsibilities of individual countries in addressing climate change. UNFCCC mandated the technology mechanism (TM) in 2010, and it became fully operational at the end of 2013. The TM supports parties in promoting and facilitating enhanced action on mitigation and adaptation (Paris Agreement, article 10.4). The Paris Agreement further specifies that the TM, together with the Financial Mechanism, will support collaborative approaches to research and development, and facilitate access to technology, in particular for early stages of the technology cycle, for developing country parties (Paris Agreement, article 10.5). The Climate Technology Centre and Network (CTCN) implements the mechanism through technology needs assessments (TNA), corresponding technology action plans (TAP), and TT:CLEAR, the web platform for all information related to climate technology. A TNA and TAP has been performed for Bangladesh. A TNA was started but remains unfinished in Nepal. In general, TNAs have been performed for several developing countries, but there are still many that have not received and/or requested technical assistance, and the CTCN seems understaffed (Shimada and Kennedy 2017). The WIM executive committee has established at the end of 2016 a technical expert group on comprehensive risk management and transformational approaches and engages regularly with the Technology Executive Committee.

The Technology Facilitation Mechanism (TFM) that supports the implementation of SDGs has similar characteristics as the UNFCCC's TM, but is still in its early stages, as it started about 5 years later. ${ }^{3}$ It aims to ensure equitable access to key

\footnotetext{
${ }^{3}$ It has three components: (1) a United Nations interagency task team on science, technology and innovation for the SDGs (IATT) with representatives from civil society, the private sector and the scientific community; (2) a collaborative multi-stakeholder forum on science, technology and innovation for the SDGs (STI Forum), which organises calls for innovations; and (3) an online platform as a gateway for information on existing STI initiatives, mechanisms and programmes (Antic and Liu 2015).
} 
Table 22.3 Transparency in the three key global agreements: reporting mechanisms, indicators related to impacts and risks, and means of implementation for technology, with some detail on Bangladesh, India and Nepal

\begin{tabular}{|c|c|c|c|}
\hline Key aspects & Climate agreements & HFA/Sendai & MDGs/SDGs \\
\hline $\begin{array}{l}\text { Reporting in } \\
\text { general }\end{array}$ & $\begin{array}{l}\text { NDC, NC, BUR and NAP, } \\
\text { NAPA, adaptation } \\
\text { communication (in } \\
\text { development). } \\
\text { Self-reporting with strong } \\
\text { review and validation } \\
\text { mechanism for mitigation, } \\
\text { not for adaptation. WIM: } \\
\text { annual reporting of ExCom } \\
\text { to COP; 2-year work plan } \\
\text { with nine action areas } \\
\text { (2014-2016); 5-year rolling } \\
\text { work plan with seven } \\
\text { strategic work streams (as } \\
\text { of 2016). Review in } 2016 \\
\text { and 2019. Request for Loss } \\
\text { and Damage contact point } \\
\text { at national level in } 2016\end{array}$ & $\begin{array}{l}\text { HFA: global, regional and } \\
\text { national progress reports, } \\
\text { global assessment report. } \\
\text { Sendai: Sendai Framework } \\
\text { progress report. } \\
\text { Self-reporting at national } \\
\text { levels }\end{array}$ & $\begin{array}{l}\text { MDG and SDG: national } \\
\text { review, self-reporting }\end{array}$ \\
\hline $\begin{array}{l}\text { Indicators related } \\
\text { to impacts and } \\
\text { risks }\end{array}$ & $\begin{array}{l}\text { Paris Agreement Article } \\
8.4 \text { Areas of cooperation } \\
\text { and facilitation: (a) Early } \\
\text { warning systems; (b) } \\
\text { Emergency preparedness; } \\
\text { (c) Slow onset events; (d) } \\
\text { Events that may involve } \\
\text { irreversible and permanent } \\
\text { loss and damage; (e) } \\
\text { Comprehensive risk } \\
\text { assessment and } \\
\text { management; (f) Risk } \\
\text { insurance facilities, climate } \\
\text { risk pooling and other } \\
\text { insurance solutions; (g) } \\
\text { Non-economic losses; and } \\
\text { (h) Resilience of } \\
\text { communities, livelihoods } \\
\text { and ecosystems. WIM: } \\
\text { three functions: (1) } \\
\text { Enhance knowledge and } \\
\text { understanding of } \\
\text { comprehensive risk } \\
\text { management approaches; } \\
\text { (2) Strengthen dialogue, } \\
\text { coordination, coherence } \\
\text { and synergies among } \\
\text { relevant stakeholders; (3) } \\
\text { Enhance action and support }\end{array}$ & $\begin{array}{l}\text { HFA: 2.2: Systems in place } \\
\text { to monitor, archive and } \\
\text { disseminate data on key } \\
\text { hazards and vulnerabilities. } \\
\text { Key question: Disaster loss } \\
\text { databases exist and are } \\
\text { regularly updated. 5.4: } \\
\text { Procedures in place to } \\
\text { exchange relevant } \\
\text { information during hazard } \\
\text { events and disasters, and to } \\
\text { undertake post-event } \\
\text { reviews. Sendai: A1 } \\
\text { Number of deaths and } \\
\text { missing persons attributed } \\
\text { to disasters per 100,000 } \\
\text { population; C1 Direct } \\
\text { economic loss attributed to } \\
\text { disasters as global gross } \\
\text { domestic product; D1 } \\
\text { Damage to critical } \\
\text { infrastructure attributed to } \\
\text { disasters; D5 Number of } \\
\text { disruptions to basic services } \\
\text { attributed to disasters }\end{array}$ & $\begin{array}{l}\text { MDG: 7A reverse the loss } \\
\text { of environmental resources. } \\
\text { 7B Reduce biodiversity } \\
\text { loss, achieving, by } 2010 \text {, a } \\
\text { significant reduction in the } \\
\text { rate of loss. SDG: } 1.5 .2 \\
\text { Direct economic loss } \\
\text { attributed to disasters in } \\
\text { relation to global gross } \\
\text { domestic product (GDP); } \\
\text { 11.5.2 Direct economic loss } \\
\text { in relation to global GDP, } \\
\text { damage to critical } \\
\text { infrastructure and number } \\
\text { of disruptions to basic } \\
\text { services, attributed to } \\
\text { disasters }\end{array}$ \\
\hline
\end{tabular}


Table 22.3 (continued)

\begin{tabular}{|c|c|c|c|}
\hline Key aspects & Climate agreements & HFA/Sendai & MDGs/SDGs \\
\hline $\begin{array}{l}\text { Previous reporting } \\
\text { on impacts and } \\
\text { risks }\end{array}$ & $\begin{array}{l}\text { Scattered reporting with } \\
\text { some aggregate numbers. } \\
\text { Nepal NC: over } 10 \text {-year } \\
\text { period up to } 2014 \text { more than } \\
4,000 \text { persons died; } \$ 5.34 \\
\text { billion lost in property, } \\
\text { land, crops and livestock. } \\
\text { India BUR } \$ 5 \text { to } 6 \text { billion } \\
\text { losses and damages } \\
2013-2014 \text {. Bangladesh } \\
\text { NC: rice yield losses as a } \\
\text { function of inundation; data } \\
\text { on infrastructure damage } \\
\text { during last } 25 \text { years due to } \\
\text { floods. Bangladesh INDC: } \\
\text { Asian Development Bank } \\
\text { estimated } 2 \% \text { GDP annual } \\
\text { loss by } 2050 \text { due to climate } \\
\text { change. Estimated damage } \\
\text { of floods in } 2007 \text { more than } \\
\$ 1 \text { billion }\end{array}$ & $\begin{array}{l}\text { HFA: only reporting on } \\
\text { level of progress achieved. } \\
\text { No data on losses and } \\
\text { damages. Sendai: data } \\
\text { readiness review shows that } \\
\text { only } 37-55 \% \text { of countries } \\
\text { report having data on } \\
\text { economic losses to } \\
\text { productive assets, losses in } \\
\text { critical infrastructure and } \\
\text { cultural heritage, and } \\
\text { disruptions to health, } \\
\text { education and other basic } \\
\text { services, with between } 29 \\
\text { and } 33 \% \text { able to develop } \\
\text { baselines }\end{array}$ & $\begin{array}{l}\text { MDGs: reporting on } \\
\text { increase of land area } \\
\text { covered by forest. SDG: } \\
\text { only voluntary national } \\
\text { reviews; none yet for } \\
\text { Bangladesh, India and } \\
\text { Nepal available. Nepal } \\
\text { Preliminary report on } \\
\text { SDG: large earthquakes in } \\
2015 \text { killed nearly } 9,000 \\
\text { people, more than } 700 \\
\text { billion Nepalese rupees of } \\
\text { damage (destroyed more } \\
\text { than half a million houses } \\
\text { and damaged more than } \\
200,000 \text { houses and public } \\
\text { offices) }\end{array}$ \\
\hline $\begin{array}{l}\text { Means of } \\
\text { implementation: } \\
\text { technology }\end{array}$ & $\begin{array}{l}\text { Technology mechanism } \\
\text { such as TNA and TAP }\end{array}$ & $\begin{array}{l}\text { Sendai: Framework with } \\
\text { science and technology } \\
\text { roadmap }\end{array}$ & $\begin{array}{l}\text { MDG: stimulation ICT as } \\
\text { enabling technology. SDG: } \\
\text { TFM, e.g. science, } \\
\text { technology and innovation } \\
\text { for SDGs forum, global } \\
\text { innovation exchange }\end{array}$ \\
\hline
\end{tabular}

Note COP Conference of the Parties, HFA Hyogo framework for action, NC national communication, BUR biennial update reports BUR, NDC nationally determined contribution, NAP national adaptation plan, NAPA national adaptation programme of action, WIM Warsaw International Mechanism for Loss and Damage, $M D G$ Millennium Development Goal, SDG Sustainable Development Goal, TNA technology needs assessments, TAP technology action plan

technologies and knowledge for developing countries. It is highly likely that it will aim at avoiding overlap with what is being covered by the UNFCCC Technology Mechanism, but some degree of synergy can be expected. So far, no reporting on TFM has been done. Technology transfer was stimulated under the MDG framework as well, whereby especially ICT was put forward as an important enabling technology. The HFA framework emphasises the importance of technical assistance, technology transfer, knowledge and innovation, but means of implementation are not very well articulated. The United Nations Trust Fund for Disaster Reduction bilateral and multilateral cooperation are put forward as possible financing mechanisms. Sendai has a section on means of implementation, where it is reaffirmed that developing countries need technology transfer on concessional and preferential terms and that thematic platforms of cooperation can be used to enhance access to technology (for example global technology pools and systems to share know-how, innovation and research) (UNISDR 2015). Also, a science and technology roadmap was developed 
to support the framework with a set of expected outcomes, actions and deliverables, mostly aimed at the scientific community (UNISDR 2016). However, these intentions have not yet led to the establishment of tangible mechanisms such as UNFCCC's CTCN.

\subsection{Reporting Framework for Technology to Address Loss and Damage and Contribute to Climate Justice}

The three key global agreements and their corresponding policy frameworks at regional, national and local level_as also discussed for Bangladesh, India and Nepal-have different ways of planning, reporting and reviewing and require the involvement of many stakeholders. The SDGs and Sendai have Loss and Damage related indicators. The Paris Agreement has no specific indicators, but the NCs do contain some usually highly aggregate losses and damages data. The reporting on adaptation is usually self-reporting without a review mechanism and standardisation that allows for comparability, done at a highly aggregate level and not specific on impact achieved. All three agreements have or are working on some form of technology facilitation for adaptation, but these mechanisms are still in their infancy, except for the TNAs. Overall, it is complex if not impossible to distil from the current transparency mechanisms a comprehensive overview of the status of progress on adaptation and its role in tackling losses and damages retrospectively or prospectively.

\section{Developing the Framework}

We thus proceed to lay out an analytical framework to analyse technology needs to reduce losses and damages for decision-makers that brings together the findings of the previous three sections, see Fig. 22.4. The framework puts centre stage two repositories that each relate impacts and risks to technology and its three components, hardware, software and orgware. One repository is an inventory of technologies used to address impacts and risks; the other repository is a target list of those technologies planned to address risk. Several repositories of technology are available that aim at connecting and matching users to technologies. ${ }^{4}$ These kinds of repositories can be used by practitioners, to select socially and environmentally sound technologies that match the needs of the poor and vulnerable/marginalised groups.

Global, regional, national and local policies have different means of implementation, i.e. technology, capacity-building and finance, as depicted on the right side

\footnotetext{
${ }^{4}$ For example, the ClimateTechWiki offers detailed information on several of the mitigation and adaptation technologies. It is a platform for a wide range of stakeholders in developed and developing countries who are involved in technology transfer and the wider context of low emission and low vulnerability development. The Technology Needs Assessment Database is complementary, with factsheets on several technologies. IEEE Engineering for Change created an online, decision-aid platform where users can search and compare technology-based solutions. The Flood Resilience Portal (www.floodresilience.net) is an online knowledge-sharing space that offers practical solutions to address the risks of flooding; the UN just started the Global Innovation Exchange.
} 


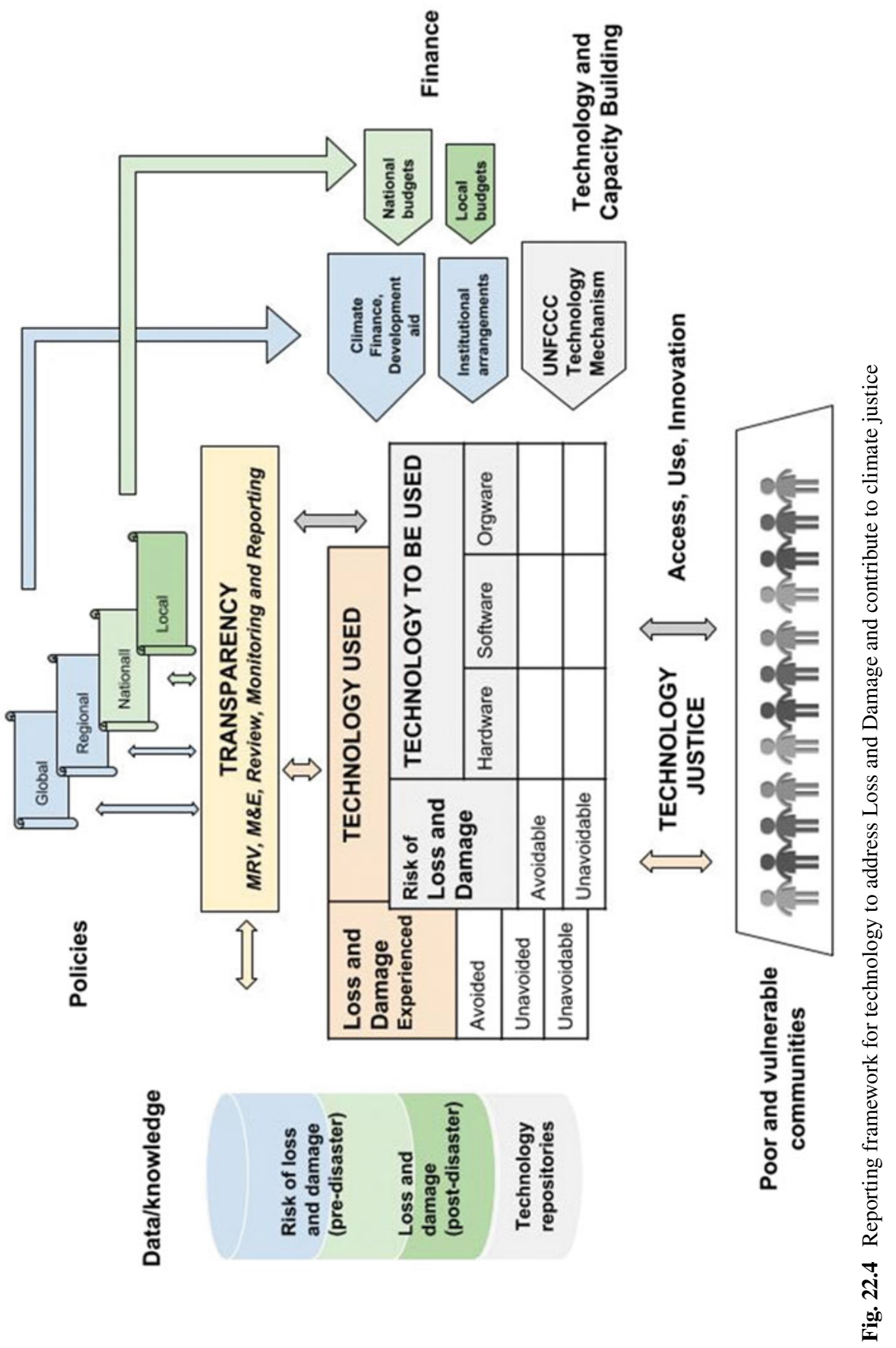


of Fig. 22.4. The key global agreements and interrelated regional, national and local counterparts each have their own specific transparency mechanism, a way of measuring, reporting and in some cases validating progress, with each their particular focus. This plethora of reporting and reviewing mechanisms covers impacts and risks only to a limited extent and does not adequately help to unveil injustices, as the reporting is often based on self-reporting at a highly aggregate level with insufficient ground-truthed data.

Therefore, credible, timely and high-quality data is an essential input for the transparency mechanism, and as shown on the left side would be kept and updated in another repository element. Reporting frameworks need to have data on access to technology that reflects actual need and on the role that technology can play in reducing losses and damage, both backward- and-forward looking. There are several approaches, methodologies and tools available to collect pre-disaster data on the risk components, i.e. vulnerability, hazards and coping capacity, and data on the actual losses and damages (Surminski et al. 2012). To maximise utility, these databases must be inclusive, capture the poor and vulnerable, be interoperable, preferably open-access, timely (regularly updated) and represent different granularity levels from global to local. It is essential to narrow the gaps in representing the poor and vulnerable of developing countries in climate data, with the ultimate objective to provide an evidence base that can be used in the policy and funding debate around climate change, as well as for DRR and development. Apart from data, knowledge is essential to assess existing and foresee new technologies for adaptation and transformation, i.e. the repositories we referred to earlier.

\section{Applying the Technology for Climate Justice Reporting Framework}

We applied the technology justice components as explained in Table 22.1 to transboundary early warning systems for the Brahmaputra River (Bangladesh-India) and the Karnali River (India-Nepal). ${ }^{5}$ Seven key experts in Nepal, India and Bangladesh provided information both in writing and through follow-up interviews.

Whereas the MDGs had no reference at all to EWS, the SDG framework has two EWS targets. Target $3 \mathrm{~d}$ is "Strengthen the capacity of all countries, in particular developing countries, for early warning, risk reduction and management of national and global health risks." Target 13.3 is to "Improve education, awareness-raising and human and institutional capacity on climate change mitigation, adaptation, impact reduction and early warning" (SDG 2016). Article 7 and Article 8 of the Paris Climate Agreement ${ }^{6}$ place a greater emphasis on understanding, action and support for EWS, but no reporting is as of yet available. Pre-2015 reports such as the national communications or the NAPAs do not have relevant data on early warning, except for more general statements. HFA and Sendai do have relevant reporting. Table 22.4 summarises the injustices for each of the components.

\footnotetext{
${ }^{5}$ The component on sustainable use does not directly apply to EWS, as EWS cause negligible intrusions such as through gauges that are put into rivers or radar installations.

${ }^{6}$ Article 7 is on "Enhancing adaptive capacity, strengthening resilience and reducing vulnerability to climate change" and Article 8 is loss and damage and "the importance of averting, minimizing and addressing loss and damage associated with the adverse effects of climate change".
} 
Table 22.4 Injustices identified in current flood early warning systems in South Asia

\begin{tabular}{|c|c|c|c|}
\hline $\begin{array}{l}\text { Proposed } \\
\text { technology for } \\
\text { climate justice } \\
\text { component }\end{array}$ & $\begin{array}{l}\text { Injustices derived from case } \\
\text { study (expert interviews, focus } \\
\text { group discussions, desk research) }\end{array}$ & $\begin{array}{l}\text { climate justice } \\
\text { principle required } \\
\text { to tackle the } \\
\text { injustice }\end{array}$ & $\begin{array}{l}\text { Adjustments } \\
\text { required to bridge } \\
\text { the gap }\end{array}$ \\
\hline $\begin{array}{l}\text { Access to } \\
\text { services }\end{array}$ & $\begin{array}{l}\text { Both national and } \\
\text { community-based EWS do not } \\
\text { effectively reach poor and } \\
\text { vulnerable communities }\end{array}$ & $\begin{array}{l}\text { Distributive, } \\
\text { normative }\end{array}$ & $\begin{array}{l}\text { Incremental and } \\
\text { fundamental }\end{array}$ \\
\hline $\begin{array}{l}\text { Access to } \\
\text { technology and } \\
\text { knowledge }\end{array}$ & $\begin{array}{l}\text { NMHS are limited in their } \\
\text { possibility to improve the spatial } \\
\text { and temporal resolution of the } \\
\text { forecasts, as they lack the } \\
\text { funding and capacity necessary } \\
\text { to use the state-of-the-art } \\
\text { technology and collect more } \\
\text { granular data. The poor and the } \\
\text { vulnerable can often not benefit } \\
\text { from early warning early action } \\
\text { information due to the digital } \\
\text { divide }\end{array}$ & $\begin{array}{l}\text { Distributive, } \\
\text { normative }\end{array}$ & $\begin{array}{l}\text { Incremental and } \\
\text { fundamental }\end{array}$ \\
\hline Use & $\begin{array}{l}\text { In assessments for } \\
\text { hard-engineering solutions for } \\
\text { flood CRM, the impact on the } \\
\text { poor and vulnerable is often not } \\
\text { considered }\end{array}$ & Procedural & $\begin{array}{l}\text { Incremental and } \\
\text { fundamental }\end{array}$ \\
\hline $\begin{array}{l}\text { Technological } \\
\text { innovation and } \\
\text { implementation }\end{array}$ & $\begin{array}{l}\text { There is not much room for } \\
\text { innovation, as the available } \\
\text { budgets usually barely cover the } \\
\text { rolling out and scaling up of } \\
\text { existing copycat-type } \\
\text { technology. In addition, capacity } \\
\text { building to roll out flood CRM at } \\
\text { local level is often not sufficient, } \\
\text { due to many ad hoc, short-lived } \\
\text { project interventions }\end{array}$ & $\begin{array}{l}\text { Procedural, } \\
\text { distributive and } \\
\text { normative }\end{array}$ & Transformative \\
\hline Governance & $\begin{array}{l}\text { Insufficient governance at } \\
\text { national to local, and national to } \\
\text { regional/neighbouring countries, } \\
\text { interfaces. Plethora of reporting } \\
\text { frameworks, lack of } \\
\text { standardisation and quantitative } \\
\text { data at sufficiently granular level. } \\
\text { Capacity for reporting is not } \\
\text { sufficient }\end{array}$ & $\begin{array}{l}\text { Procedural and } \\
\text { transitional }\end{array}$ & $\begin{array}{l}\text { Fundamental and } \\
\text { transformative }\end{array}$ \\
\hline Finance & $\begin{array}{l}\text { Limited funding for public } \\
\text { adaptation is going to the } \\
\text { least-developed countries, and } \\
\text { the poor and vulnerable have } \\
\text { very limited funding for private } \\
\text { adaptation actions }\end{array}$ & $\begin{array}{l}\text { Compensatory, } \\
\text { distributive }\end{array}$ & Transformative \\
\hline
\end{tabular}




\section{Equitable Access to Early Warning}

The focus of National Meteorological and Hydrological Services (NMHS) is on calculating accurate forecasts nationwide. However, ensuring equitable access to these forecasts also for poor and vulnerable communities is not core to their mandate. Community-based early warning systems (CBEWS) try to bridge this gap, but they do not cover all flood-prone communities, provide only very short lead times and are not well integrated with national systems, hampering their sustainability. Communities that do not receive an early warning inevitably face higher losses and damages, but even those that do receive an early warning often do not have sufficient information to take well-targeted (early) actions that could limit or avoid losses and damages. It is key to characterise the early warning-early action gap to a sufficiently quantitative extent and not - as is currently the case for HFA - in a multi-hazard, country-wide and mostly qualitative way. The self-reporting on access in the HFA, and soon Sendai, has to be interpreted carefully, as the reporting is, to our current understanding, not based on representative surveys conducted by governments among communities that depend on early warning. In general, local self-reporting seems to give a more realistic picture than national self-reporting.

\section{Equitable Access to Technology and Knowledge}

Access to services and technology is far from equitable both at the public and private level. Access to more advanced flood risk modelling and observational data, including the required advanced computational power, enables NMHS to improve the spatial and temporal precision of the EWS. This in turn allows for better targeting of adaptation actions for reducing or avoiding losses and damages. Poor and vulnerable communities face digital disparities, impeding equitable access to early warning and early action information.

\section{Technological Innovation and Implementation}

Communities are better able to manage and utilise CBEWS when they are involved in the technology development process from the onset. The dissemination, communication and response component of EWS can benefit from relatively low-tech innovations, whereas the risk modelling and monitoring and warning components require both low and high-tech innovations. Current policies and plans have identified several of these innovation needs, but available budgets usually barely cover the rolling out and scaling up of existing copycat-type technology. In addition, capacity building to roll out flood CRM at local level is often not sufficient, due to many ad hoc, short-lived, mainly project-based interventions (Khan et al. 2016).

\section{Governance}

Many organisations are involved in implementing EWS at local, national, regional and global level. Most CBEWS initiatives start at the project or pilot level and face difficulties in scaling up and becoming sustainable. It is at the national to local and national to regional/neighbouring countries' interfaces that current governance is insufficient. Governance has to occur across these different dimensions, to promote synergy and coherence and to create political and financial support for using new 
technologies to reach the communities that need the information. In addition, there are a plethora of reporting frameworks and a lack of standardisation and quantitative data at sufficiently granular level. High-resolution spatial data on whether/how adaptation technologies meet the needs of the poor and vulnerable is required for the focal scale of flood impacts and interventions, but is lacking. It is complex if not impossible to distil from the current transparency mechanisms a comprehensive overview of the status of progress on adaptation and its role in reducing losses and damages. Clearly capacity for reporting is not sufficient and self-reporting of countries to the global policy agreements tends to lead to too-optimistic scoring, as is seen for example in terms of the reach of early warning into poor and vulnerable communities.

\section{Finance}

We find in the transboundary EWS case study area that costs for bridging the gap towards communities are currently not covered through structural and comprehensive funding streams. There is evidence from Bangladesh that shows that these costs form a significant percentage of the overall EWS costs. Innovations in the area of local data collection are urgently needed to reduce the current costs for data collection of water levels. Targeted crowdsourcing might be cost-effective to collect local data for flood maps as compared with costly gauges and gauge readers; at the same time, it will bring along uncertainties in relation to the continuity and validity of the collection. To convince policy makers and practitioners, it is essential that a more mature, longitudinal and standardised assessment of losses and damages at community level takes place against investments that are being made in EWS.

Overall, we suggest the framework proves to be an adequate mechanism to assess the injustices present in a flood CRM measure, such as a transboundary EWS, along the technology dimension. This assessment forms a starting point for change. In Table 22.4 we indicate in the third column which climate justice principle is applicable to tackle these injustices. For example, procedural justice means making sure the poor and vulnerable are included in evaluating a flood CRM measure. The fourth column in Table 22.4 estimates what kind of adjustment is necessary to bridge the gap between an unjust and just situation. Improving access to services can be a quick win with mostly incremental adjustments. However, funding and governance might require transformative adjustment.

\subsection{Discussion and Conclusions}

This chapter assessed the role of technology for the L\&D debate and developed a reporting framework that links climate justice principles to access, use, innovation, finance and governance of technology to address loss and damage at the crossover from adaptation to "beyond adaptation" from the perspective of the poor and vulnerable. Application of the framework to a case study on a flood EWS showed that developing countries (as well as poor and vulnerable communities in these countries) can only use a small part of the technology spectrum available to address loss 
and damage as they have limited capacities and funding for innovating, accessing and using technology. They are therefore forced to implement the bare minimum largely copycat type of technology. As climate change progresses, the level of adaptation required increases, whereas if no action is taken, the technology available for adaptation remains the same. This means the adaptation deficit (Burton 2004) will increase.

We argued that attention to climate justice principles can help to motivate support for widening the technology spectrum available to developing countries and for addressing the injustices we inventoried by distributing means of implementation (technology, finance and capacity building) through underlying principles such as distributive, compensatory, transitional or procedural justice. We hold that global communities have a responsibility to ensure sustainable use of, equitable access to and inclusive innovation of technology to shape the soft adaptation limit and, once this limit is reached, to support transformative and curative measures necessary to tackle additional risks due to climate change.

In this concluding section, we build on the framework in order to develop recommendations for the Paris Agreement and WIM as to how technology can be mobilised to contribute to climate justice. As the required actions are partly in the adaptation and partly in the L\&D pillar, recommendations will cover both. We organise our suggestions around the three main functions of the WIM (understanding, dialogue and support plus action).

\section{Understanding $L \& D$}

Understanding the switch from adaptation to L\&D enables improved investment in technologies for adaptation while clarifying the unavoidable risks requiring curative or transformative action. We emphasise that this will be possible up to the hard limit, after which only L\&D measures are possible. The executive committee of the WIM may include in the work stream and expert group on comprehensive risk management an inventory of how technologies shape the soft limits in both developing and developed countries. It will also be important to reach a solid basis and agreement on what the hard limits from a technological point are for climate change risks, such as for sea-level rise, to avoid contentious political discussions on operationalising the L\&D mechanism.

\section{Dialogue, Coordination and Coherence on Loss and Damage}

Parties may want to link dialogue, coordination and coherence to the transparency mechanism under Article 7, as the WIM does not have a transparency mechanism. Article 7 of the Paris Agreement states that each party should periodically submit an adaptation communication, which may include its priorities, implementation and support needs, plans and actions. In this context, Article 13 states that, under the transparency framework, countries are encouraged — without it being mandatory-to report information on their adaptation actions to highlight what they have done and what more needs to be done (Desgain and Sharma 2016). The transparency framework offers flexibility in the scope, frequency and level of detail of reporting, and in the scope of review (Kato and Ellis 2016). There is a window of opportunity as part of the facilitative dialogue to start a discussion on including technology in 
the adaptation communication and to make sure reported data captures the actual impact of adaptation on impacts and risks and represents the poor and vulnerable. However, reporting on adaptation has the risk of shifting the burden to developing countries if efforts to reduce risks are seen as their responsibility (ECBI 2017). It therefore has to go hand in hand with a further development of reporting on the WIM mechanism. It is also important to treat technology in coherence with the SDG and Sendai framework, and join forces in reporting on losses and damages in the broader sense (including L\&D). A kind of devolution hub ${ }^{7}$ that makes access to policies at global, regional, national and local level easily available and interpretable might be beneficial to stimulate coherency. In addition, standardisation of how to measure and report on losses and damages will be essential.

\section{Action in Relation to Technology to Contribute to Climate Justice}

In many instances, communities and countries still seem to have room for adaptation between the soft and hard limit, as indicated by the reported avoidable impacts and risks. Countries are expected to implement adaptation measures to the best of their capabilities (meaning up to their soft limit) to protect their populations from climate variability and/or to empower their citizens, especially those with the lowest capacity to adapt (Winkler and Rajamani 2014) ,to implement corresponding risk avoidance measures, given the common responsibility for adaptation. Governments should provide essential services for DRR, such as a basin-scale EWS making use of automated data collection, high-resolution satellite imagery and impact-based forecasting. But insufficient funding for adaptation is going to the least-developed countries, and the poor and vulnerable have limited access to technologies required for individual adaptation, let alone for keeping up with future risk trends.

Technology can play a role in creating additional adaptation options and/or shifting the soft adaptation limit. Soft adaptation limits should be levelled between developing and developed countries. This means that the objectives that shape the adaptation limit should not be different. Technologies should be shared among those countries having access and those not having access, recognising the commitment to leave no one behind. Why would an NMHS in a developing country settle for less EWS lead time than in a developed country? The technologies that do play a role in transformative actions are in general different from climate-related technologies, for example ICT technologies for distance learning or for outsourcing IT work. Technological development and proliferation has to involve all stakeholders in a fair and equal manner (procedural justice). It is essential to create funding possibilities for developing appropriate technology within existing technology mechanisms such as from the CTCN. The voices of the poor and vulnerable have to be heard. It does not all need to be high-tech; many local technologies can be adapted with investment in research, such as biodykes for flood mitigation, with the added benefit that they can be maintained by local people with existing skill sets.

The transparency framework we propose overall exposes injustices in technology innovation, access and use, with the objective of widening the technology spectrum

\footnotetext{
${ }^{7}$ Such as from the OpenInstitute, see http://www.openinstitute.com/devhubv2.
} 
available to developing countries by distributing means of implementation (technology, finance and capacity building) through underlying climate justice principles.

Acknowledgements The Zurich Flood Resilience Alliance supported this work. The authors gratefully acknowledge input by the following experts from Practical Action: Jonathan Casey, Christine Comerford (UK), Gopal Ghimire, Dinanath Bhandari, Gehendra Gurung and Sumit Dugar (Nepal), Rigan Ali Khan (Bangladesh) and K. R. Viswanathan (India).

\section{References}

Antic A, Liu W (2015) Options of an online platform of a technology facilitation mechanism. IATT Background Paper No. 2015/2. https://sustainabledevelopment.un.org/content/document s/2153OnlineTechnology\%20Facilitation\%20Knowledge\%20Platform\%20Oct\%2028\%20201 5_clean_final.pdf. Accessed 28 Oct 2015

Boldt J, Nygaard I, Hansen UE, Trærup S (2012) Overcoming barriers to the transfer and diffusion of climate technologies. Roskilde, Unep Ris $\varnothing$ Centre on Energy, Climate and Sustainable Development

Boyd E, James RA, Jones RG, Young HR, Otto FE (2017) A typology of loss and damage perspectives. Nat Clim Change 7(10):7223

Bridgeman T (2017) Paris is a binding agreement: here's why that matters. https://www.justsecurit y.org/41705/paris-binding-agreement-matters/. Accessed 4 Jun 2017

Burton I (2004) Climate change and the adaptation deficit. In: Fenech A, MacIver D, Auld H, Bing Rong R, Yin Y (eds) Climate change: building the adaptive capacity. Environment Canada, Meteorological Service of Canada, Gatineau, QC, Canada, pp 25-33

Chaudhury A, Sova C, Rasheed T, Thorton TF, Baral P, Zeb A (2014) Deconstructing local adaptation plans for action (LAPAs): analysis of Nepal and Pakistan LAPA Initiatives. Working Paper 67. CGIAR Research Program on Climate Change, Agriculture and Food Security (CCAFS), Copenhagen, Denmark. http://papers.ssrn.com/sol3/papers.cfm?abstract_id=2496968. Accessed 28 Oct 2015

Christiansen L, Olhoff A, Trærup S (eds) (2011) Technologies for adaptation: perspectives and practical experiences. UNEP Ris $\varnothing$ Centre, Roskilde

Clark D (2011) Which nations are most responsible for climate change. The Guardian April 21, 2011

Climate Centre (2017) Hydropower and humanitarian sectors joining forces to combat flood risk. http://www.climatecentre.org/news/849/hydropower-and-humanitarian-sectors-joining-for ces-to-combat-flood-risk. Accessed Apr 212018

Coughlan de Perez E, van den Hurk B, van Aalst MK, Amuron I, Bamanya D, Hauser T, Jongman B, Lopez A, Mason S, Mendler de Suarez J, Pappenberger F, Rueth A, Stephens E, Suarez P, Wagemaker J, Zsoter E (2016) Action-based flood forecasting for triggering humanitarian action. Hydrol Earth Syst Sci 20:3549-3560. https://doi.org/10.5194/hess-20-3549-2016

Cumiskey L, Altamirano M, Hakvoort H (2014) Mobile services for flood early warning, Bangladesh: Final Report. In: Deltares, Cordaid, RIMES, Flood Forecasting and Warning Center, The Netherlands

Desgain DDR, Sharma (2016) Understanding the paris agreement: analysing the reporting requirements under the enhanced transparency framework

Dow K, Berkhout F, Preston BL (2013) Limits to adaptation to climate change: a risk approach. Current Opinion Environ Sustain 5(3):384-391

ECBI (European Capacity Building Initiative) (2017) Pocket Guide to Transparency. http://www.e urocapacity.org/downloads/Pocket_Guide_Transparency_under_UNFCCC/mobile/index.html\# $\mathrm{p}=1$. Accessed 24 Jun 2017 
ETC Group (20110) Gene Giants Stockpile Patents on 'ClimateReady' Crops in Bid to Become Biomasters. Communiqué no. 106. http://www.etcgroup.org/en/node/5221. Accessed 28 October 2011

Etkin D (1999) Risk transference and related trends: driving forces towards more mega-disasters. Global Environ Change B: Environ Hazards 1(2):69-75

Freudenburg WR, Gramling R, Laska S, Erikson KT (2008) Organizing hazards, engineering disasters? Improving the recognition of political-economic factors in the creation of disasters. Soc Forces 87(2):1015-1038

Government of Nepal (2016) Nationally determined contributions. http://www4.unfccc.int/ndcreg istry/PublishedDocuments/Nepal\%20First/Nepal\%20First\%20NDC.pdf. Accessed Apr 2018

Hallegatte S, Vogt-Schilb A, Bangalore M, Rozenberg J (2016) Unbreakable: building the resilience of the poor in the face of natural disasters. World Bank Publications

Handmer J, Nalau J (2018) Understanding loss and damage in Pacific Small Island developing states. In: Mechler R, Bouwer L, Schinko T, Surminski S, Linnerooth-Bayer J (eds) Loss and damage from climate change. Concepts, methods and policy options. Springer, Cham, pp 365-381

Haque M, Pervin M, Sultana S, Huq S (2018) Towards establishing a national mechanism to address loss and damage: a case study from Bangladesh. In: Mechler R, Bouwer L, Schinko T, Surminski $\mathrm{S}$, Linnerooth-Bayer J (eds) Loss and damage from climate change. Concepts, methods and policy options. Springer, Cham, pp 451-473

Heslin A (2018) Climate migration and cultural preservation: the case of the marshallese diaspora. In: Mechler R, Bouwer L, Schinko T, Surminski S, Linnerooth-Bayer J (eds) Loss and damage from climate change. Concepts, methods and policy options. Springer, Cham, pp 383-391

Heslin A, Deckard D, Oakes R, Montero-Colbert A (2018) Displacement and resettlement: understanding the role of climate change in contemporary migration. In: Mechler R, Bouwer L, Schinko T, Surminski S, Linnerooth-Bayer J (eds) Loss and damage from climate change. Concepts, methods and policy options. Springer, Cham, pp 237-258

Huntington HP, Goodstein E, Euskirchen E (2012) Towards a tipping point in responding to change: rising costs, fewer options for Arctic and global societies. Ambio 41(1):66-74

IISD (2011) Climate risk management technical assistance support project. Dominican country study: climate risk management in the water sector. http://unfccc.int/files/adaptation/knowledg e_resources/databases/partners_action_pledges/application/pdf/iisd_furtherinfo_water_190411. pdf. Accessed 28 Oct 2015

IPCC (2012) Summary for policymakers. In: Field CB, Barros V, Stocker TF, Qin D, Dokken D, Ebi KL, Mastrandrea MD, Mach KJ, Plattner G-K, Allen S, Tignor M, Midgley PM (eds) Adaptation. 2012 intergovernmental panel on climate change special report on managing the risks of extreme events and disasters to advance climate change. Cambridge University Press, Cambridge, United Kingdom and New York, NY, USA

IPCC (2014) Climate change 2014: synthesis report. In: Core Writing Team, Pachauri RK, Meyer LA (eds) Contribution of working groups I, II and III to the fifth assessment report of the intergovernmental panel on climate change. IPCC, Geneva, Switzerland, $151 \mathrm{pp}$

James RA, Jones RG, Boyd E, Young HR, Otto FEL, Huggel C, Fuglestvedt JS (2018) Attribution: how is it relevant for loss and damage policy and practice? In: Mechler R, Bouwer L, Schinko T, Surminski S, Linnerooth-Bayer J (eds) Loss and damage from climate change. Concepts, methods and policy options. Springer, Cham, pp 113-154

Kates RW, Travis WR, Wilbanks TJ (2012) Transformational adaptation when incremental adaptations to climate change are insufficient. Proc Natl Acad Sci 109(19):7156-7161

Kato T, Ellis J (2016) Communicating progress in national and global adaptation to climate change. http://www.oecd-ilibrary.org/environment/communicating-progress-in-national-a nd-global-adaptation-to-climate-change_5jlww009v1hj-en. Accessed 28 Oct 2016

Khan M, Sagar A, Huq S, Thiam PK (2016) Capacity building under the Paris Agreement. http://www.eurocapacity.org/downloads/Capacity_Building_under_Paris_Agreement_20 16.pdf. Accessed 28 Oct 2016 
Klein RJT, Midgley GF, Preston BL, Alam M, Berkhout FGH, Dow K, Shaw MR (2014) Adaptation opportunities, constraints, and limits. In: Field CB, Barros VR, Dokken DJ, Mach KJ, Mastrandrea MD, Bilir TE, Chatterjee M, Ebi KL, Estrada YO, Genova RC, Girma B, Kissel ES, Levy AN, MacCracken S, Mastrandrea PR, White LL (eds) Climate change 2014: impacts, adaptation, and vulnerability. Part A: global and sectoral aspects. Contribution of working group II to the fifth assessment report of the intergovernmental panel on climate change. Cambridge University Press, Cambridge, United Kingdom and New York, NY, USA, pp 899-943

Klinsky S, Brankovic J (2018) The global climate regime and transitional justice. Routledge Advances in Climate Change Research, forthcoming

Klinsky S, Waskow D, Bevins W, Northrop E, Kutter R, Weatherer L, Joffe P (2014) Building climate equity. Creating a new approach from the ground up, World Resource Institute (WRI), Summary Report

Landauer M, Juhola S (2018) Loss and damage in the rapidly changing arctic. In: Mechler R, Bouwer L, Schinko T, Surminski S, Linnerooth-Bayer J (eds) Loss and damage from climate change. Concepts, methods and policy options. Springer, Cham, pp 425-447

Link LE (2010) The anatomy of a disaster, an overview of Hurricane Katrina and New Orleans. Ocean Eng 37:4-12

Martin, M, Walker J (2017) Financing the sustainable development goals. Lessons from government spending on the MDGs. https://policy-practice.oxfam.org.uk/publications/financing-the-sustain able-development-goals-lessons-from-government-spending-on-556597. Accessed Apr 2018

Maskrey A (2016) Monitoring progress in disaster risk reduction in the Sendai framework for Action 2015-2030 and the 2030 sustainable development agenda. http://eird.org/ran-sendai-2016/prese ntaciones/D2S2P1-ANDREW-MASKREY.pdf. Accessed 9 Jun 2016

Mechler R et al (2018) Science for loss and damage. Findings and propositions. In: Mechler R, Bouwer L, Schinko T, Surminski S, Linnerooth-Bayer J (eds) Loss and damage from climate change. Concepts, methods and policy options. Springer, Cham, pp 3-37

Mechler R, Schinko T (2016) Identifying the policy space for climate loss and damage. Science 354(6310):290-292

Moser SC (2010) Now more than ever: the need for more societally relevant research on vulnerability and adaptation to climate change. Appl Geogr 30(4):464-474

Munich Re NatCatService (2017) Natural catastrophe losses at their highest for four years. https://www.munichre.com/en/media-relations/publications/press-releases/2017/2017-0 1-04-press-release/index.html. Accessed 23 Oct 2017

Mysiak J, Surminski S, Thieken A, Mechler R, Aerts JC (2016) Brief communication: Sendai framework for disaster risk reduction-success or warning sign for Paris? Nat Hazards Earth Sys Sci 16(10):2189-2193

National Planning Commission (2015) Sustainable development goals, 2016-2030. National (Preliminary) Report. http://www.np.undp.org/content/dam/nepal/docs/reports/SDG\%20final\%20re port-nepal.pdf. Accessed 12 Apr 2018

O’Brien K, Pelling M, Patwardhan A, Hallegatte S, Maskrey A, Oki T, Oswald-Spring U, Wilbanks T, Yanda PZ (2012) Toward a sustainable and resilient future. In: Field CB, Barros V, Stocker TF, Qin D, Dokken DJ, Ebi KL, Mastrandrea MD, Mach KJ, Plattner G-K, Allen, Tignor M, Midgley PM (eds) (2012) Managing the risks of extreme events and disasters to advance climate change adaptation. A special report of working groups I and II of the intergovernmental panel on climate change (IPCC). Cambridge University Press, Cambridge, UK, and New York, NY, USA, pp 437-486

Pauw WP, Cassanmagnano D, Mbeva K, Hein J, Guarin A, Brandi C, Dzebo A, Canales N, Adams KM, Atteridge A, Bock T, Helms J, Zalewski A, Frommé E, Lindener A, Muhammad D (2016) NDC explorer. German Development Institute/Deutsches Institut für Entwicklungspolitik (DIE), African Centre for Technology Studies (ACTS), Stockholm Environment Institute (SEI). https:// doi.org/10.23661/ndc_explorer_2017_2.0

Raworth J (2012) A safe and just space for humanity: can we live within the doughnut? Oxfam Policy Practice: Clim Change Resil 8(1):1-26 
Regmi BR, Cassandra S, Walter LF (2016) Effectiveness of the local adaptation plan of action to support climate change adaptation in Nepal. Mitig Adap Strateg Global Change 21.3(2016):461-478

Schinko T, Mechler R (2017) Applying recent insights from climate risk management to operationalize the loss and damage mechanism. Ecol Econ 136:296-298

Schinko T, Mechler R, Hochrainer-Stigler S (2018) The risk and policy space for loss and damage: integrating notions of distributive and compensatory justice with comprehensive climate risk management. In: Mechler R, Bouwer L, Schinko T, Surminski S, Linnerooth-Bayer J (eds) Loss and damage from climate change. Concepts, methods and policy options. Springer, Cham, pp $83-110$

Shimada K, Kennedy M (2017) Potential role of the technology mechanism in implementing the Paris Agreement. http://unfccc.int/ttclear/misc_/StaticFiles/gnwoerk_static/events_SE-TEC-C TCN-COP21/d093a44fa4b34caabe125562e66b80b9/0595db8c40d34226be9b58999e59ba78. pdf. Accessed 26 Oct 2017

Simpson AL, Balog S, Moller DK, Strauss BH, Saito K (2015) An urgent case for higher resolution digital elevation models in the world's poorest and most vulnerable countries. Front Earth Sci 3:50. https://doi.org/10.3389/feart.2015.00050

Subsidiary Body for Implementation (2012) A literature review on the topics in the context of thematic area 2 of the work programme on loss and damage: a range of approaches to address loss and damage associated with the adverse effects of climate change. http://unfccc.int/resourc e/docs/2012/sbi/eng/inf14.pdf. Accessed 12 April 2018

Surminski S, Lopez A, Birkmann J, Welle T (2012) Current knowledge on relevant methodologies and data requirements as well as lessons learned and gaps identified at different levels, in assessing the risk of loss and damage associated with the adverse effects of climate change

Tomlinson L (2015) Procedural justice in the United Nations Framework convention on climate change. Springer International Publishing

Trace S (2016) Rethink, retool, reboot, technology as if people and planet mattered. Rugby, United Kingdom, Practical Action Publishing

Transparency Partnership (2017) Preparing for the new transparency framework-lessons learned, challenges, next steps. https://www.transparency-partnership.net/preparing-new-transparency-fr amework-\%E2\%80\%93-lessons-learned-challenges-next-steps. Accessed 27 May 2017

Turner RE, Baustian JJ, Swenson EM, Spicer JS (2006) Wetland sedimentation from hurricanes Katrina and Rita. Science 314(5798):449-452

UN (2015) Transforming our world: the 2030 Agenda for Sustainable Development, A/RES/70/1. http://www.refworld.org/docid/57b6e3e44.html

UNESCAP (2015) Overview of natural disasters and their impacts in Asia and the Pacific, 1970-2014. http://www.unescap.org/sites/default/files/Technical\%20paper-Overview\%20of\%2 0natural\%20hazards\%20and\%20their\%20impacts_final.pdf. Accessed 11 May 2016

UNFCCC (2006) Application of environmentally sound technologies for adaptation to climate change (FCCC/TP/2006/2). https://unfccc.int/sites/default/files/resource/docs/2006/tp/tp02.pdf. Accessed 10 Apr 2018

UNFCCC (2013) Decision 2/CP.19: Warsaw international mechanism for loss and damage associated with climate change impacts. http://unfccc.int/resource/docs/2013/cop19/eng/10a01.pdf\#p age $=6$. Cited 13 Nov 2015

UNFCCC (2014) Handbook on Measurement, Reporting and Verification for developing country parties. http://unfccc.int/files/national_reports/annex_i_natcom_/application/pdf/non-annex_ i_mrv_handbook.pdf. Accessed 28 May 2017

UNFCCC (2015) Adoption of the Paris Agreement. Decision FCCC/CP/2015/L.9 https://unfccc.i nt/resource/docs/2015/cop21/eng/109r01.pdf. Cited 13 Feb 2016

UNISDR (2015) Sendai framework for disaster risk reduction 2015-2030. http://www.unisdr.org/ files/43291_sendaiframeworkfordrren.pdf. Accessed 31 Mar 2015

UNISDR (2016) The science and technology roadmap to support the implementation of the Sendai Framework for disaster risk reduction, 2015-2030. http://www.preventionweb.net/files/45270_ unisdrscienceandtechnologyroadmap.pdf. Accessed 25 Feb 2016 
UNISDR (2017) Global summary report Sendai framework data readiness review 2017. http://www. unisdr.org/files/53080_entrybgpaperglobalsummaryreportdisa.pdf. Accessed 28 Oct 2017

van der Geest K, Warner K (2015) Editorial. Loss and damage from climate change: emerging perspectives. Int J Global Warming 8(2):133-140

Verheyen R (2012) Tackling loss \& damage—a new role for the climate regime. Bonn, Germany, pp $1-12$

Walker G (2009) Beyond distribution and proximity: exploring the multiple spatialities of environmental justice. Antipode 41(4):614-636

Wallimann-Helmer I, Meyer L, Mintz-Woo K, Schinko T, Serdeczny O (2018) The ethical challenges in the context of climate loss and damage. In: Mechler R, Bouwer L, Schinko T, Surminski S, Linnerooth-Bayer J (eds) Loss and damage from climate change. Concepts, methods and policy options. Springer, Cham, pp 39-62

Winkler H, Rajamani L (2014) CBDR\&RC in a regime applicable to all. Clim Policy 14(1):102-121

Winsemius HC, Aerts JCJH, van Beek LP, Bierkens MF, Bouwman A, Jongman B, Kwadijk JCJ, Ligtvoet W, Lucas PL, van Vuuren DP, Ward PJ (2015) Global drivers of future river flood risk. Nat Clim Change 6(4):381

World Bank (2010) Bangladesh-Economic of adaptation to climate change Main report. Washington, DC: World Bank. http://documents.worldbank.org/curated/en/841911468331803769/M ain-report. Accessed 28 May 2016

Open Access This chapter is licensed under the terms of the Creative Commons Attribution 4.0 International License (http://creativecommons.org/licenses/by/4.0/), which permits use, sharing, adaptation, distribution and reproduction in any medium or format, as long as you give appropriate credit to the original author(s) and the source, provide a link to the Creative Commons license and indicate if changes were made.

The images or other third party material in this chapter are included in the chapter's Creative Commons license, unless indicated otherwise in a credit line to the material. If material is not included in the chapter's Creative Commons license and your intended use is not permitted by statutory regulation or exceeds the permitted use, you will need to obtain permission directly from the copyright holder.

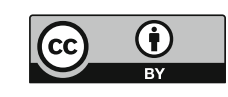

